'Ordo' versus 'Ordnung'

Catholic or Lutheran roots of German ordoliberal economic theory?

Krarup, Troels

Published in:

International Review of Economics

DOI:

10.1007/s12232-019-00323-y

Publication date:

2019

Document version

Peer reviewed version

Citation for published version (APA):

Krarup, T. (2019). 'Ordo' versus 'Ordnung': Catholic or Lutheran roots of German ordoliberal economic theory? International Review of Economics, 66, 305-323. https://doi.org/10.1007/s12232-019-00323-y 
‘Ordo’ versus ‘Ordnung’: Catholic or Lutheran Roots of German Ordoliberal Economic Theory?

Troels Krarup*

* (Corresponding Author) Troels Krarup, PhD, Post-Doctoral Fellow, Department of Sociology, Copenhagen University, Øster Farimagsgade 5, 1353 Copenhagen K, Copenhagen, Denmark, +4535 3363 38. ORCID: 0000-0002-7239-2221. Correspondence: tr.krarup@gmail.com

Published as: Krarup, T. (2019). 'Ordo versus Ordnung? Catholic or Lutheran roots of German ordoliberal economic theory?' International Review of Economics 66(3): 305-323. DOI: https://doi.org/10.1007/s12232-019-00323-y

\section{Acknowledgements}

The work presented in this paper was financed by the Gerda Henkel Foundation (AZ 24/V/17), whom the author would like to thank. 


\title{
‘Ordo’ versus ‘Ordnung’: Catholic or Lutheran Roots of German Ordoliberal Economic Theory?
}

\begin{abstract}
Ordoliberalism is a German tradition of economic and political theory whose influence on the post2008 European landscape has been substantial. Ordoliberalism professes a strong state to safeguarding competition against monopolies, argues for a strickt anti-inflationary policy and for the rigid enforcement of debtor obligations. This reflects the early ordoliberalism's deep concern with the political and economic crises in Germany during the interwar years. The article demonstrates that early ordoliberalism was simultaneously deeply concerned with religious issues related to social order. Rather than seeing religious and economic engagements as two separate spheres, the article shows their deep interrelatedness in early ordoliberal thought. More specifically, the article seeks to challenge the established view that the religious inspirations of early ordoliberalism were predominantly Catholic, as reflected in the Thomist notion of ordo. By contrast, the article argues that ordo was largely an invention of the post-war strategy of the alliance with Catholic social thought and that the deeper concern of the early ordoliberals was predominantly with Lutheran Evangelical Ordnung.
\end{abstract}

Keywords: ordoliberalism, theology, religion, economic theory, discourse, archaeology JEL: A12 Relation of Economics to Other Disciplines, A13 Relation of Economics to Social Values, B29 History of Economic Thought since 1925: Other 


\section{Introduction}

Ordoliberal economic theory has dominated the post-war German political landscape and by many scholars it is considered crucial to the understanding of the North-South rift in the post-2008 political landscape of the European Union (Bulmer 2014; Hillebrand 2015; Matthijs and McNamara 2015; Nedergaard and Snaith 2015; Young 2014, 2017; for critiques, see Hien and Joerges 2017a; Feld et al. 2015). Ordoliberals embrace competitive markets, but they simultaneously profess a strong technocratic state to safeguard competition against monopolies and political power (Mudge 2008; Bonefeld 2010, 2012; Davies 2014). Other characteristics of ordoliberalism include a strong commitment to low inflation, tight antitrust regulation of competitive markets, rigid enforcement of debtor responsibilities, and a watertight separation between government borrowing and central bank lending. In other words, ordoliberalism has several features distinguishing it within the "neoliberal thought collective' to which scholars in general assign it (Mirowski and Plehwe 2009). It is not rooted in the individualism of classical, Austrian and Anglo-Saxon versions of (neo-)liberalism.

In this paper, I show that the political and economic theory of early ordoliberalism and the diagnosis of the political and economic turmoil in Germany during the interwar years in response to which it was first formulated can only be adequately understood by taking into account the deep Lutheran Evangelical faith and philosophical and theological engagement of the main protagonists like Walter Eucken, Franz Böhm, Alfred Müller-Armack, Constantin von Dietze, Alexander Rüstow and Wilhelm Röpke. As Manow (2001) has shown, the founding fathers of early ordoliberalism in the 1930s through the 1950s were all devout Lutheran Evangelicals. This Protestant heritage in ordoliberalism has played a decisive role in the post-2008 North-South split in Europe (Magatti and Martinelli 2016; Hien 2017). Emphatically, the argument advanced here is not that the early ordoliberals were driven by religious and theological concerns as opposed to economic theory. By contrast, my argument is that according to the early ordoliberals there was no such opposition. 
Economic, political, philosophical and theological arguments are intertwined by them them as a matter of course. Consequently, I argue, their religious and philosophical outlooks fundamentally shaped their core economic concepts like 'competition order'. While traditional history of economic thought generally operates (somewhat anachronistically) from a distinctly modern conception of what is economic and what is not economic - relegating, for instance, theology to the non-economic elements in the sources that are hence often disregarded - I seek to trace the lines of demarcation made in the sources themselves and to analyse the (sometimes very diverse) ways in which 'the economic' is conceived in them compared to our contemporary conception.

I am not the first to analyse the role played by religious concerns in early ordoliberalism (Goldschmidt 1998; Manow 2001; Jähnichen 2010; Bonefeld 2017a; Hien and Joerges 2017b). The originality of the present contribution, therefore, lies in a more specialized question in the existing literature. While the traditional history of economic thought has focused narrowly on the 'economic' (in the modern sense) aspects of early ordoliberalism, in the more narrow scholarship on the intellectual roots of ordoliberalism the widespread view is that the main theological heritage in ordoliberalism comes not from Protestant, but from Catholic sources. In particular, research has emphasised the explicit reference to Thomist scholasticism in the name that ordo-liberalism chose for itself. The article shows that while the Thomist tradition is not entirely absent, the main concern in early ordoliberalism was rather with Lutheran worldly Ordnung than with Catholic cosmic ordo. Both may be translated into English as 'order', but they have very different meanings, they designate different areas of applicability, reflect different intellectual concerns and generate different problems and debates with different historical roots. In brief, the Latin ordo in the Catholic tradition refers to Divine order, while the German Ordnung in the Lutheran tradition refers to the ordination of worldly authority by God. 
While Weber analysed the Calvinist trajectory of influence on modern Northern Euroepan and Anglo-Saxon economic thinking, the specifically Lutheran heritage is at first a more difficult one to grasp, since Luther himself opposed the power of money in all its shapes and forms: religious (indulgence), political (papacy), economic (usury) and private (luxury) (Bruni et al. 2016). But as argued in this article, the Lutheran heritage in the case of ordoliberalism does not come with Calvenist culture or liberal Protestant social movements, nor does it consist in the adoption of specific economic dogmas from Luther's writings. Rather, ordoliberalism developed from a distinct complex of concepts and problems related to the question of social order (Ordnung) rooted in the distinct Lutheran Evangelical tradition of 'political ethics' in Germanophone countries during the interwar years. Thus, from a historical perspective 'ordo-liberalism' would be better designated as Ordnungsliberalism.

Section 2 discusses the 'archaeological' methodology to the historical study of theories (Libera 2014). Section 3 presents the dominant view that ordoliberalism is rooted in the scholastic concept of ordo and assesses the extent to which this heritage is relevant. Section 4 argues that early ordoliberalism is marked by far more profoundly by Lutheran Evangelicalism and the concept of Ordnung. The section also traces this concept from the Bible via Luther and Lutheran 'political ethics' to the founding fathers of ordoliberalism in the 1930s through the 1950s. Section 5 concludes and discusses the implications of this shift of focus for our understanding of ordoliberalism as an influential modern economic theory.

\section{Philosophical Archaeology}

There is a rich scholarship of conceptual history relating in general to the purposes of the present article (Richter 1997; Koselleck 2002). At a more specific level, however, I have opted for the Foucaultian tradition of 'archaeology' as practiced most recently by Alain de Libera (2014, 2016). 
Building on Foucault (2008), Libera (2014) defines archaeology as the history of migrations, translations and alterations of a complex of concepts, problems and theoretical responses - what Foucault calls a discourse. Thus, in archaeology it is important not to start out from a once fixed definition of the theoretical concept or tradition of interest. In the present case, we should avoid to define ordoliberalism from the outset by a number of fixed doctrinal tenets or the concept of order by either one or another meaning or heritage. Rather, we should seek to identify and account for a series of changing debates, conceptualizations and core problems, and give room for discontinuities, contradictions and disagreements (Libera 2016).

What binds a number of historical enunciations together is not identity in terms of doctrinal affiliation or theoretical language, but the engagement with the same 'problem structure' (structure problématique) (Libera 2014). This relates to Althusser's (Foucault's teacher) notion of the 'problematic' of a theoretical practice as the core conceptual concern around which it is organized (Althusser 2014). It likewise relates to Hyppolite's (1974) influential (being a teacher of both Foucault and Althusser) reading of Hegel, according to which no concept is identical with itself, but is determined in a discrepant and tense relation to other concepts. The 'problem structure', then, is the core of the mutually determining relationships between concepts, concerns and problems in a theoretical discourse - not a doctrinal unity. As a consequence, archaeology does not see conceptual contradictions and theoretical conflicts as necessarily dividing different discourses, but as playing out on 'the field of available enunciations' of a single discourse (Libera 2014). ${ }^{1}$

Therefore, when inquiring into Luther's heritage in modern economic thought from an archaeological angle, we should not expect to uncover simple doctrinal identities across theology and

\footnotetext{
${ }^{1}$ While Libera (2016) and Agamben (2009a) both use the term 'philosophical archaeology', they differ significantly in their accounts of it, as Libera relies on a close reading of Foucault's Archaeology and a familiarity with the contemporary French academic discussions in which it is situated and which altered fundamentally the original Kantian conception (Hegel read by Hyppolite, Althusser's concept of problematics), where Agamben produces an ontologized variant of his own (ontology being ruled out from Foucaultian archaeology and discourse analysis) with the help of Mauss and Heidegger.
} 
economics and across the span of four or five centuries. In fact, we may very well discover deep disagreements not only between, but also within both Lutheranism and ordoliberalism making such an endeavor impossible in the first place. We may even discover theoretical contradictions at the core of the writings of a single author. What we may have a chance to find, however, is that such disagreements and contradictions - along with the production of affiliated doctrinal positions that accompanies them - may be exactly what constitutes the 'heritage' from Luther in early ordoliberalism, provided that the intermediating alterations can be accounted for. In other words, we may find Lutheran concerns, concepts and problems - supposedly of predominantly theological character - that have migrated, been translated and altered into related concerns, concepts and problems in early ordoliberal economic and political theory, even when such heritage has not been conscious or explicit (see Libera 2014).

\section{Ordo-liberalism}

It is a widespread view, yet rarely supported by systematic analysis of the sources, that ordoliberalism takes its concept of ordo from Thomist scholastic theology. While the founding fathers of early ordoliberalism were Lutheran Evangelicals (Manow 2001) and while the notion of order they professed in their writings was primarily a specific kind of economic order (market competition) supported by the authority of an allegedly depolitizised state (Bonefeld 2012), the historical lineage emanating from Thomas Aquinas would suggest a close affiliation with Catholic social thought along with a distinct Western philosophical apparatus for dealing with the question of power. In this section, I show that while this thesis bears some relevance in the specific case of the ordoliberal philosophy of (economic) science, it is based partly on erroneous presumptions, and that it misses the most central characteristics of the ordoliberal concept of order. 
Recently, there has been some interest in the possible influences of Carl Schmitt's writings on early ordoliberalism (Tribe 2008; Streeck 2015; e.g., Bonefeld 2017b). This literature relies heavily on two early mentionings of Schmitt's work by Eucken and Rüstow who both - in the very same texts - reject theories, such as Schmitt's, of the 'total state' (Eucken 1932a; Rüstow 1932). At best, Schmitt's 'political theology' bears ideological affinity with early ordoliberalism at a high level of generality (Tönnies 2009), as Bonefeld (2012) also admits. More substantially, Schmitt (2016 [1923]) is clearly inspired by Catholic political thought in unequivocally stating that state authority should be inherently political - where 'political' is to be understood in opposition to the anonymous mechanisms of the market. By contrast, the ordoliberals favored a strong but de-politicized state and saw the value of the market precisely in its anonymous and mechanistic way of imposing order. As early as 1955, Friedrich (1955) observed in the American Political Science Review that ordoliberalism had adopted its concept of ordo from Thomist scholasticism. Johnson (1989) - in his biographical work on the chief economist of early ordoliberalism, Walter Eucken, and two other prominent ordoliberals, Wilhelm Röpke and Alexander Rüstow - notes Eucken's interest in Max Scheler, a phenomenologist and philosopher, and goes so far as to suggest that Scheler's 'frequent use of the Augustinian concept of ordo may well have been the immediate source of the title of Walter Eucken's later journal'. According to Johnson, while for German bureaucrats at the time 'order' was something that was imposed 'from above', i.e., by the state, Eucken and his fellows thought that 'the order appropriate to the market is that which derives from the immanent law of nature, the medieval ordo' (Johnson 1989). ${ }^{2}$ Johnson admits that it is a weak point that Eucken himself never mentioned this, but his wife in her prologue to the first issue of $O R D O$ - the name chosen by the ordoliberals for their new journal in 1948 - summoned Grotius who 'adapted Medieaval natural law to the modern law of nations' (Johnson 1989). Similarly, Ptak (2009, note 8) notes Eucken's (2004) definition of ordo in

\footnotetext{
2 This assessment is erroneous. As we shall see, it is precisely the order imposed from above, according to Eucken, that allows competition to prosper and endure.
} 
Thomist ontological terms as 'the meaningful junction of variety to a whole'. It is worthwhile noticing tha the reference to scholasticism occurs only in the appendix to the post-humously published Grundsätze der Wirtschaftspolitik. Moreover, the definition provided by Ptak covers only one of the two sides of the definition of order given by Eucken, the other side being positive historical orders (see also Goldschmidt 1998).

Ptak's observation is taken up by Dean (2013) who uses it to link to Agamben's (2009b) analysis of the concept of ordo in Catholic theology from Augustine to Aquinas as a foundational ontological problem for all Western political thought. Saint Augustine (354-430) defines ordo as the adequate hence peace-making, hence good - arrangement of things. He does so in an ontological sense, so that even 'disorder' and 'evil' occur within order. Order is a kind of immanent gold standard in the world, according to Augustine, against which disorder and evil are defined (Augustine 1960). For Thomas Aquinas (1225-1274), ordo has the same sense of the adequate arrangement of things. According to Aquinas, order is manifest and evident in nature and thereby testifies that this world is being directed towards (gubernare) a certain end by providence. And so Aquinas defines 'Good' as God's directing things towards their destined ends (Aquinas 1975). For human beings (creaturae rationales), the case is slightly different from that for the things of nature, because the former has the free will to impose its own ends on things by force (violentiam) within this world. But God's ends lie beyond this world and hence beyond the order itself (Aquinas 1975).

Agamben (2011) seems, correctly, to suggest - albeit without stating it clearly - that the theological conceptual machine of ordo has an inbuilt problem of ontology: Across its different historical variants, ordo may take the shape of 'Truth', 'God', 'Being' or other universals. The fundamental problematic with universals is how to reconcile ordo as (a) the very essence of this world when it must simultaneously be (b) outside and beyond the varying historical states of the world (see also Althusser 2014; Hindess 1977). But while this critique of ontology is certainly relevant, it will 
not give us the key to understanding early ordoliberalism and the link between theology and modern economic theory as the dominant reading of ordo-liberalism would suggest. Its relevance is limited, and it concerns predominantly the philosophy of science of Walter Eucken.

When Walter Eucken and the jurist Franz Böhm chose the name $O R D O$ for their journal of which the first issue was published in 1948, they had the rare fortune to name their own current of thought rather than to have a name put upon them by adversaries or posterity. But it is noteworthy that ordoliberalism emerged in the interwar years - not after WWII - and that the choice of the name of their journal came at a time when this current-without-a-name sought for an alliance with the Catholics for political influence (Manow 2010). Their successful attempt had a substantial imprint on the policy of the ruling Christian Democratic Union (CDU) party in post-war West Germany. In other words, the reason why ordoliberalism adopted the term 'ordo', I argue, was the political strategy of alliance with Catholics around the Christian Democratic Union (CDU) party that soon gained power in Germany. Engagement by the ordoliberals in discussions with Catholics in the post-war years is strong. For example, both Rüstow and Müller-Armack contributed to the Catholic volume on Christ and the Social Market Economy (Boarman 1955). In his contribution, Rüstow (1955) argues that Catholic social thought would have to adapt to the market economy and the kind of indirect 'solidarity' it implies, according to him, and that despite more fundamental confessional disagreements they could easily agree on political visions. The very term 'social market economy' which came to characterize the post-war German economy was coined by Müller-Armack immediately following the 1945 peace in his 'irenic' efforts to unite Protestantism, Catholicism and 'new liberalism' (Müller-Armack 1968a [1950]; Manow 2010). Indeed, before the end of WWII ordoliberalism had no traces of neither 'ordo' nor 'social'. Tribe (2008) has demonstrated that 'the extremely limited attention given by Ordoliberals to the linkage between economic and social policy' before and during WWII. Likewise, there is simply no mentioning of 'ordo' in ordoliberal writings 
before the first issue of the ORDO journal. Here, the translation of Eucken, Böhm and GrossmannDoerth's foreword to the first volume of their new book series Ordnung der Wirtschaft published in 1937 (Böhm 1937) by Peacock and Willgerodt as 'The Ordo Manifesto' has been misleading for the English-speaking audience (Böhm et al. 1989).

It may be objected that Müller-Armack, a sociologist of religion in the tradition of Weber and another protagonist of early ordoliberalism, asserts that the choice of ' $O R D O$ ' was not theoretically arbitrary: Protestants, Socialists, and Liberals, according to him, were not capable on their own to lay the 'Christian groundwork' necessary for the 'future design of society' in the same way as 'the Catholic social theory has been for a long time' (Müller-Armack 1968a). But Müller-Armack simultaneously declared Catholic social thought to be outdated and demanded that Catholics bowed to the recent achievements of economic science, which had 'over the last decades conceived the principles of free competition as a useful social order [gesellschaftsnützliche Ordnung] in a social sense' (Müller-Armack 1968a). Rüstow, too, in his very outreach to Catholics for political alliance, firmly rejected the Catholic notion of solidarity in terms of charity in favour of one rooted in the competitive market (Rüstow 1955). So, too, does Eucken reject the insistence on social orders (Stände) of modern Catholic social thought as epitomized in the 1931 papal enclitic Quadragesimo anno (Eucken 2004).

As we shall see in section 4, if we give less weight to words ('ordo') and more to concerns, concepts and problems of a theoretical discourse, we shall largely have to reject the common view that ordoliberalism builds on scholastic ground. However, there is one aspect - particularly in Walter Eucken's writings - which does concern a concept of ordo, namely the ordoliberal philosophy of science. 


\subsection{Ordoliberal Philosophy of Science}

In two of his main works on economics, Eucken $(1934,1939)$ exhibits a profound engagement with philosophical questions almost entirely neglected by the existing literature on ordoliberalism. He was the son of a neo-Kantian philosopher of some renown in his own time, thus familiar with this philosophical tradition, and he was the editor and regulary contributer to the journal created in his name: Tatwelt: Journal for the Renewal of Spiritural Life (Dathe 2009). In his Grundlagen der Nationalökonomie (Eucken 1939), he opens with a discussion of Descartes and devotes the first chapters to issues of philosophy of science, establishing his rationalist position in opposition to classical empiricism. In Was leistet die Nationalökonomie (Eucken 1934), he quotes not only economists like Smith, Pareto and Cassels, but also - and substantially so - philosophers like Spinoza, Leibniz, Kant, Husserl, Lotze, Hume and Comte. To understand his perspective on economic theory as presented in his major works, therefore, we need to take into consideration his philosophical views and concerns as well.

Orders, according to Eucken, are the historically specific organization or arrangement of a society or a sector of society - such as the economy or a subsector of the economy, e.g., a specific market within which social and economic processes play out (Eucken 1943). But these historical orders are not objective truths in themselves, and hence not the true object of social science. However, they do reflect objective, universal and absolute 'order forms'. The order forms make up the finite totality of possible forms of orders, not only in the past, but also in the future (Eucken 1943). It is with reference to this double definition of historical orders and order forms that Eucken would later refer to the latter as ordo (Eucken 2004).

According to Eucken, order forms cannot be immediately perceived, nor are they simple 'averages' of historical orders. Rather, they constitute a 'morphological apparatus', that is, the dimensionality of variation in historical forms conceptualized in terms of ideal-typical orders (Eucken 
1943). The order forms cannot be perceived directly, but the researcher must formulate them as a 'logical necessities' (Denknotwendigkeit) that can, in turn, be used to understand specific historical orders (Eucken 1934). ${ }^{3}$

Eucken thus distinguishes between truth and reality. 'Truth' (Wahrheit) is the 'Essence' (Wesen) of historical reality, but is not reality (Wirklichkeit) itself. Historical reality is composite and mottled. By contrast, Truth is purely intellectual - and yet, it is important to produce theories that 'contain truths that are close to reality [wirklichkeitsnahe]' (Eucken 1934). And vice versa, for empirical science to be 'objective' in Eucken's sense, they must not simply describe historical reality, but support the conceptualization of objects in theory(Eucken 1934). The objects of science are not empirical things, but the hidden 'objective Truth' of the ordo.

Based on his explicitly rationalist position in the philosophy of science, Eucken believes to have overcome nothing less than the 'great antinomy' between concrete historical analysis and abstract theoretical work that has haunted the search for Truth in the Occident since Plato (Eucken 1934, 1943). This 'achievement' is lauded by his ordoliberal colleague, Konstantin von Dietze, who reiterates that "the possibility of so doing derives from thinking in "economic orders"” (Dietze 1947). In other words, the concept of 'orders' in ordoliberal philosophy of science acts as a mediator between objective truth and historical reality. It is an ontological category (a dogma about the Truth of Being) that allows an epistemology (a dogma about how to access Truth behind reality) to be developed.

The presumed achievement, however, runs into problems. Eucken holds that the orders are both the very essence of history and the condition of this essence outside history itself. They are simultaneously 'the pure, constitutive, ideal typical fundamental form ... that are found in all epochs of human history and that can be conquered [by the human intellect] based on the exact observation of the different scientific disciplines and through ideal typical [pointierend hervorhebende; as

\footnotetext{
${ }^{3}$ Moreover, Eucken 'considers it a human obligation (Menschheitsanliegen) to ensure that among the possible social orders, the ones inhabited by the nature of ordo are given [political] priority' (Goldschmidt 1998).
} 
opposed to generalizing] abstraction' and the 'non-historical theoretical propositions [nichtzeitgebundener theoretischer Sätze]' that are 'true' as 'logical necessities [Denknotwendigkeiten]' although not 'actual' in concrete history (Eucken 1943). This problem is precisely the problem of ontology, as identified by Agamben in the case of the ordo of Catholic theology. In Eucken's case, too, 'order' must simultaneously be (1) the universal framework or space of possibility outside history itself within which particular historical reality plays out and (2) the inner essence of that particular historical reality. In other words, there is both an essential and a non-essential part of historical reality - the former belongs to the realm of truth, the latter does not. One is perplexed by this consequence: Some aspects of reality are not true. Moreover, it is impossible to grasp within the confines of logic how the essential part of historical reality can also, at the same time, be universal truth outside historical reality (see also Althusser 2014; Hindess 1977).

Rather than abolishing the inbuilt contradiction of ontology that has shaped Western thought since the Middle Ages (Libera 2014), as Eucken himself claims to have achieved, the contradiction manifests itself in Eucken's economic theory as problems of reductionism and indeterminability. At the most fundamental level of the 'order forms', Eucken distinguishes between degrees of (a) planned economy and (b) exchange (market) economy. Within the latter, he distinguishes 25 sub-forms depending on the degree to which supply and demand respectively are monopolized or competitive. And for each of these forms he distinguishes between 'open' and 'closed' variants - thus totaling precisely 100 'objectively given order forms' of market economy 'that orccur in the real economy' (Eucken 1943). In other words, objective truth is in fact extremely simple. ${ }^{4}$

The only problem is that Eucken's schema is tautological - either it rains or it does not; either the circulation of goods is planned or it is not; either supply and demand are monopolized or they are not; either it is open or it is closed. As a formulation of Truth it is therefore arbitrary. Moreover, the

\footnotetext{
${ }^{4}$ The simplicity of the schema is used by Eucken and other early ordoliberals to position ordoliberalism as a 'third way' between raw capitalism and despotical socialism.
} 
argument supporting the specific formulation of Truth in terms of 100 order forms is circular: Since 'real' historical orders never accord with a single order form but are complex mixtures of these, all historical realities can be fitted into the schema on an ad hoc basis; and since no concrete historical order can be found or conceived of that does not fit the schema in some way, the schema reflects objective, universal and absolute truth.

It is no coincidence if this ressembles Saint Augustine's paradoxical claim that Evil is part of Good because both arguments face the inbuilt problem of ontology. And it would not be surprising if ordoliberals had engaged in just as long and vehement a discussion of Eucken's definition of orders as theologians have in the case of the existence and nature of God. But ordoliberals have not done so because this is not the core problematic of ordoliberalism. As the remainder of the article will demonstrate, the more specific and distinctive religious heritage in the ordoliberal concept of order is the Pauline-Lutheran problematic of aligning obedience to worldly authorities and to loving one's neighbour. How can this be done when worldly authorities use force and require you to do the same against your neighbour in their name - not only as a police officer, but also simply by keeping contracts that may result in bankruptcy of one's neighbour?

\section{Ordnungs-liberalism}

For the early ordoliberals, economic theory and religious and philosophical reflection were not two mutually excluding activities. Contrary to the demarcations characterizing mainstream economics today, early ordoliberalism is simultaneously economic and theological. Consequently, religious and economic concepts are mutually dependent at determining in ordoliberalism and it would be a mistake to isolate them from each other. For example, according to Eucken, no order form realizes itself, but requires humans to employ their freedom in making it actual in history. Thus, in his view, it was a grave mistake of the classical liberals to believe that the best of the order forms - competition order 
(Wettbewerbsordnung) - had the force to actualise itself and therefore to promote laissez faire policy and a confined night-watchman state (Eucken 2004; see also Böhm 1960). The failure of laissez faire, however, was not just an economic and political phenomenon. Fundamentally, it was also a religious phenomenon. In his 'Religion - Economy - State', Eucken argues that the political and economic turmoil of the 1930s was the result of a long process beginning with the French Revolution through which man had come to be no longer seen as a sinner 'that only divine mercy can redeem' (Eucken 1932b). Through this process, according to Eucken, belief in the state has replaced belief in God, but the acts of every individual man could only recover 'the encompassing interrelation of meaning' through 'religion, belief in God' and that '[o]nly then will a certain calm enter in the social and political field again too' (Eucken 1932b). The same thesis is also put forward and treated in extensive historical and theological detail by Müller-Armack (Müller-Armack 1948) and in the ordoliberal 'Bonhoeffer Memorandum' (Freiburger Kreis 1979) as well as by Brunner (1978) and Gogarten (1932). Rüstow likewise asserts that the classical liberal economists' mistake was based on a 'false' and 'pagan deist theology' - a 'belief in harmony', in 'a harmony pre-stabilised by God' (Rüstow 1955, 1960). By contrast, he argues, 'man has in this world great and difficult assignments [Aufgaben] that must be fulfilled' (Rüstow 1960). To the early ordoliberals, the 'failure of economic liberalism' was hence above all a problem of the history of religion (Rüstow 1945; Müller-Armack 1948; Eucken 1932b).

This is also where the ordoliberals - including Eucken - break explicitly with the Catholic idea of ordo as 'orders of creation' that are lasting arrangements of this world, unalterable to human beings (Dietze 1947). Any state, according to Catholic thought, has a specific telos: to impose laws in accordance with natural law; and so does the economy: 'the supply of material goods to the people' (Dietze 1947). Dietze contrasts this with the Lutheran-Evangelical tenet that nothing human including any social or economic order - is eternal, but finite, as opposed to the eternity of God. 
Therefore, no specific economic system can be privileged or treated as sacred, i.e., as belonging or emanate from God - only, some economic orders may be more in accordance with Christian ethics than others (Dietze 1947). This resonates well with the position of other Germanophone Lutheran Evangelical intellectuals at the time who tended to think of orders, not in ordo terms of fixed godgiven social structures, but as Ordnung, as necessary but abstract forms (such as marriage, state and church), the specific content of which it was up to historically situated human beings to fill in as their political assignment (Aufgabe) according to Christian conscience and the requirements of the historically specific situation (Gogarten 1932; Brunner 1978).

According to the 'Bonhoeffer Memorandum' - a 1943 underground writing on social order post Nazi collapse authored by Dietze, Eucken, and Böhm, among other Freiburger academics and published after the war - it is a fallacy of the Aristotelian-Thomist tradition to seek the proscriptions for a just human society in the Bible or in the 'orders of creation' (historical reality) (Freiburger Kreis 1979). While the authors of the Memorandum confirm the possibility of 'a state erected on the basis of the principles of Christian morality", they firmly reject the idea of an "Evangelical" or "Christian" state as such, since no earthly order of power and justice ought to claim the right to bring about the Kingdom of God on earth (Freiburger Kreis 1979). Even the Law of Moses is 'no code containing norms of justice, but an instruction for conscience' to act towards one's neighbour in love of God and in view of the final judgement (Freiburger Kreis 1979, my italics; see also Calvin 1911).

Under the influence of Barth (2010 [1919/1922]), Germanophone Lutheran Evangelicalism was heavily concerned with Saint Paul's discussion of the correct Christian attitude towards wordly authorities in the Epistle to the Romans, which is also a central topic of discussion in Luther's work (Luther 1931, 1960, 1964, 1966). According to St. Paul, to love one's neighbour, to not resist the evildoer, and to not claim to be just or to know justice - these essential Christian commandments entail that Christians must also obey worldly authority (Rom. 13,2). Worldly authorities 'have been 
instituted by God' (Rom. 13,1). This claim is repeated by Luther (1966 [1523]) in his work On Worldly Authority. It is against this backdrop the ordoliberal Memorandum states that: 'for us, everything hinges on further developing the Lutheran doctrine of Christian authority on the basis of the infinitly rich historical-political experience that we have acquired in the meantime' (Freiburger Kreis 1979, my italics).

As opponents to the Nazi regime, the authors of the Memorandum sought a way to uphold the Pauline-Lutheran injunction to obey worldly authority without depriving themselves as human beings of their ethical and political obligation to struggle against evil in the world. In this, they situated themselves in an ongoing debate within Germanophone Lutheran Evangelical theology following Barth (2010) - in particular the 'political ethics' of Emil Brunner, Friedrich Gogarten and Paul Althaus (Röpke 1944; Müller-Armack 1968b; Freiburger Kreis 1979; all of which are occasionally mentioned in early ordoliberal writings e.g., Eucken 2004).

The Lutheran Evangelical concept of Ordnung concerns a problem of mediating between the apparently contradictory Pauline requirements for Christian conscience: (a) to love unselfishly one's neighbour in faith of God; (b) to obey and serve worldly authority, however despotical. This problem became very pressing for the early ordoliberals, not only due to the experience of the Nazi regime, but also to what they thought of as the two-front war against despotical socialist central planning and the decomposition of society under both laissez-faire capitalism and interest-group-based parliamentarism (see Eucken 1932b; and his intervention at the "Liberalism and Christianity" session at the Mont Pelerin Society 1947). How could the Christian at one and the same time (a) unselfishly serve his neighbour; (b) disinterestedly serve the state; (c) actively fulfil his assignment of political engagement against human sin and evil in society? To the early ordoliberals, the concept of Ordnung was the response to this problem. More specifically, competition order (Wettbewerbsordnung) of a free and fair market framed by a strong, but depolitizised technocratic state apparatus to check the 
accumulation of power at the hands of single enterprises or political interest groups was the 'scientific' (based especially on Eucken's work on economics) ideal order towards which human kind should strife.

\subsection{Love your Neighbour and Competition Order}

According to the early ordoliberals, the Christian should resist all political forms that would not check the excessive accumulation of economic and political power or would elevate human beings to the level of the divine - the ordoliberals thereby distanced themselves from both humanism, classical liberalism, human rights, socialist utopias and Nazi idolatry of Führer and Volk (Müller-Armack 1948; Freiburger Kreis 1979). ${ }^{5}$ The Christian should struggle for a strong but de-politizised state apparatus which does not serve the interests of the specific group in power, but instead counters the formation of political and economic power groups. This is best done, according to the ordoliberals, by exposing everyone to the same degree of ordered competition - not to the brutal Law of the Jungle of laissez-faire, but to ‘fair competition’ (Rüstow 1932, 1955; Böhm 1989 [1966]; Böhm et al. 1989 [1936]).

Rüstow argues that Christian solidarity and loving one's neighbour is not about one individual showing charity to another individual, as the Catholics hold, but is a political task of creating an Ordnung in which individuals are not subjected to the power and intentions of others, but only to the anonymous forces of fair competition (Rüstow 1955). 'The competition order forces even the pure egoists to act in the common interest' and is 'the only order that bends the powers of egoism' while remaining anonymous and disinsterested (Eucken 2004). The price mechanism is what makes this

\footnotetext{
5 This position distances them from the 'German Christians' - the dominant fraction within the German Evangelical Church which embraced Nazi rule. Nazi ideologists too, not least of Carl Schmitt, employed the word Ordnung and there was some interaction between these two traditions. Some order theologians (Althaus, Gogarten) and even ordoliberals (Müller-Armack) supported the Nazi rule for shorter or longer periods of time and with varying enthusiasm. But in general, the ordoliberal current early on opted for political liberalism and a rejection of Führer idolatry (Johnson 1989; Dathe 2009).
} 
happen. Thus, in the ordoliberal competition order, man is enabled to fulfil his Christian 'duty' to provide for himself and his intimates. The system does not have to rely on alms, but allows every individual to fulfil his moral obligation to work (Rüstow 1955; Freiburger Kreis 1979; Eucken 2004).

This builds directly on the theological tradition of Lutheran Evangelicalism. Both Paul and Luther emphasised that man is evil in all his desires, interests and acts. Only by eliminating these can the Christian be just. Not by any 'good deeds', but only by faith alone can the Christian love his neighbour and fulfil his duty (Rom. 3,10-20). As Luther repeats incessantly in his Cathecism, all that sinful human beings can and must do is to love, trust, and fear God. Love and faith - the essence of Christianity - is strictly spiritual.

In a slight but important modification of the Lutheran interpretation of St. Paul, Barth stated that the reason for obeying worldly authorities is purely negative: Since man does not and cannot know justice, he has no ground on which base a revolt against the established rule (Barth 2010). The injunction is not a defence of worldly authority, according to Barth, but an attack on man's 'intention towards the hights', his idolatry (Barth 2010). But to the followers of Barth, Ordnung became the solid ground for Christian ethics because it consisted not in positive demands and proscriptions for individuals, but was an anonymous, divine social form that allows Christians to serve their neighbour through the obedience to worldly authorities as a religious assignment (Aufgabe) (Althaus 1923; Gogarten 1932; Brunner 1978). In their view, this had precisely the advantage to impose order in society without attempting the impossible: to elevate certain human beings and their human sense of justice above sin (e.g., above corruption and power abuse). This tradition of Lutheran Evangelical thinking took the name 'political ethics'.

The modern liberal state had failed, according to Gogarten, because it is based on a human conception of equality, while the true Polis rules over its citizens as dependent and obedient (Gogarten 1932). Polis erects barriers to the unfolding of human evil (desires and interests) by the 
historically given authority in which 'one man is placed above another, not as individual, but as the bearer of a duty' (Gogarten 1932). Based on authority, the Polis protects the other orders - most importantly those of family, economy, state, justice, and customs (Gogarten 1932). And Polis provides freedom - not in terms of absolute individual rights, but in mutual dependence towards others: 'freedom of responsibility' (Gogarten 1932). Political freedom only emerges through the orders (Gogarten 1932).

Brunner adds that serving the historical orders is 'always a service rendered to one's neighbour', and that 'fitting into the given historical order is the first word of Christian ethics' because it reflects the divine order forms (to use Eucken's expression) of family, state, economy, justice, customs, and so on (Brunner 1978). Hence, 'loving one's neighbour' is not the romantic or heroic 'good deed' done for a specific individual, but serving one's 'official duty' in the orders:

The 'official duty' is 'coarse', factual-technical, and the relationship to other people required by it is an outward one, a process of mastering the masses. Indeed, it can seem in utter contradiction to love. Its implementation necessitates force, perhaps physical force, and even killing. ... The Christian sees in these orders God's disciplining [Zucht] of us sinfull human beings, but also - at the same time - sees sin itself (Brunner 1978).

Here, Brunner follows Luthers Pauline argument that 'God's will is that the worldly sword and justice must be enforced for the punishment of the evildoers [Bösen] and for the protection of the pious' (Luther 1966). To use the sword - even to kill - is completely in accordance with 'loving one's neighbour', if only it be done in the name of, and as a service to, worldly authority, and not out of selfish motives (the same point is made by Calvin 1911, likewise with reference to St. Paul). 
The concept, concern and problem of Ordnung that organized early ordoliberalism as an offspring of Lutheran Evangelical political ethics is thus very different from the ontological one of ordo in the Catholic tradition. It concerns not the Kingdom of God on earth, not individual charity and not the formation of a humane society. Rather, it concerns the political promotion of a social order exercising its powers anonymously, so as to avoid putting it into the hands of interested individuals (sinful human beings) and hence allowing the Christian to serve the wordly authorities as his divine assignment in good faith.

This concern has deep historical conceptual roots. In Romans, it is stated that: 'whoever resists authority resists what God has appointed, and those who resist will incur judgment' (Rom. 13,2). St. Paul uses the Greek diatage ( $\delta i \alpha \tau \alpha \gamma \tilde{\eta})$ where the English version has 'what God has appointed'. Diatage can also be translated with 'order', if one bears in mind its conotations of 'ordination', 'commandment', or 'regulation'. Saint Jerome's Vulgate has 'Dei ordinationi' - meaning God's 'ordination', 'regulation' or 'arrangement' - not ordo. And Luther's (2003 [1522]) German translation of the Bible has 'Gottis ordnung'. The conceptual history of Ordnung in German Protestant theology is thus different from that of ordo in the scholastic sense. Scholastic ordo has its roots in another Greek word - the Aristotelian taxis ( $\tau \dot{\alpha} \xi \zeta \varsigma)$, which also counts 'order' among its meanings, but with connotations of 'system', 'rank', 'class', 'composition' or 'sequence' (just like the Latin ordo) (Ritter and Gründer 1984). Ordoliberalism emerged from the mainly Protestant history of Ordnung - or diatage, ordination - rather than the Catholich one of ordo.

Within the Lutheran Evangelical tradition, intentionality is put centre-stage of the Protestant attempt to align loving one's neighbour and social order. One may kill if one does so in 'executing God's law' - including that of the given worldly authority since it is appointed by God. But one may not do so if one does it in the name of some human sense of justice or group interest - as the peasentry did on Luther's time when revolting against political and economic oppression from their lords 
(Luther 1964 [1525]). It is only through this tradition that the early ordoliberal conception of a strong but anonymous state promoting fair competition can be adequately comprehended. The selfish and egoistic drives are what make humans sinful, according to Luther. According to the ordoliberals, 'competition order', is 'the only order that bends the powers of egoism' (Eucken 2004).

Interestingly, the ordoliberal view seems to permeate the European Union today - not only in the political struggles during the Eurocrisis, but also at the level of legal structures of the Internal Market. As Massimiliano Vatiero has shown, rulings by the European Court of Justice has promoted dominant firms to act 'as if' they did not possess monopoly power (Vatiero 2015). In other words, the problem of market power in the EU does not seem to be conceived so much in terms of power as such, but rather of the intentional exercise of power in one's own interest.

\section{Conclusion}

In early ordoliberalism, the Lutheran Evangelical problem of synthesizing obedience to worldly authorities with loving one's neighbour translates into a problem of the political power which is necessary to impose and maintain order. This problem is not only about the risk of abuse of power, but also about how to use force legitimately without violating the injunction to love one's neighbour. The concept of order surfaces in ordoliberalism as a solution to this central theoretical problem - not as ordo, but as Ordnung in the Germanophone tradition of Lutheran Evangelical political ethics. Ordnung is not about the aporia of relating individual and society or reality and truth. Rather, it is determined by distinctly Lutheran conceptions of freedom, worldly authority, and loving one's neighbour. Analysing Ordnung within this conceptual compound has revealed the specific motivation in early ordoliberalism for simultaneously promoting competititive markets and a strong state.

Specifically, 'competition order' - a free market combined with a strong de-politizised state - is the ordoliberal response to how power can be exercised so as to curb human egoism without itself 
falling prey to that sinful desire. Competition order is not about producing socially optimal outcomes based on fundamental individual rights, but about taming sin as a purely spiritual phenomenon (desire, egoism) and providing viable conditions for loving one's neighbour. By contrast, the free market under laissez-faire capitalism, according to the ordoliberals, is a hotbed for sinful and atheist egoism. To ordoliberals, the strong state is neither there to protect the 'free' market, nor to 'regulate' it, but to produce and underpin 'competition order'. Competition order may provide individuals with freedom, but not in the sense of absolute rights. Rather, ordoliberal freedom consists in the preservation from social chaos and from power being hijacked by human interests or by a human sense of justice $(\sin )$. Hence, there is no absolute reason why, for example, that state should be a democracy (see also Manow 2010). In ordoliberalism, freedom is not a humanist absolute, but a spiritual given; the state is neither good (only God is) nor evil (only individual human beings are), but it may serve the good precisely in so far as it remains neutral and curbs human egoism. By contrast, when hijacked by individuals, private enterprises or group interests, the state apparatus has by definition fallen into the hands of Evil. What the ordoliberal market economy produces in the end is not a socially optimal state, but the necessary conditions for individuals to engage in relations of mutual dependence and obedience with one another.

At this point, I would like brieftly to reiterate a methodological point made in section 2, which can now be illustrated with examples from the analysis in sections 3 and 4 . The argument here is not that there is a simple doctrinal unity - let alone ideological or theoretical coherence - running from St. Paul over Luther and political ethics to early ordoliberalism. We have already seen a number of discrepancies, disagreements and contradictions withing the discourse: (a) while Ordnung dominates, there are also elements of ordo in ordoliberalism, yet we also find firm rejections of the ordo tradition; (b) the irresolvable contradiction of ontology at the core of the ordoliberal philosophy of science; (c) Barth (1934) rejected political ethics and the early ordoliberals were critical of it (Eucken 1932b; 
Freiburger Kreis 1979; Eucken 2004); (d) the ordoliberals disagreed vehemently among themselves on certain issues (see, for instance, Rüstows letters to Eucken and Röpke, Rüstow 1946a, b). What we have seen is rather a number of concerns, concepts and problems that are closely intertwined in their deployment across Lutheran Evangelical and early ordoliberal discourse, which also helps to trace and to understand the emergence of new concepts such as 'competition order' as responses to the same 'problem structure' within that discourse.

It would be inappropriate, albeit tempting, to extrapolate grand conclusions about ordoliberalism in Germany and the EU today from the analysis presented in this paper. It will require a full-blown research project to decide whether Ordnung has maintained its centrality and determinations in ordoliberal discourse between 1945 and 2018. We have seen that discursive stability across wide spans of history is indeed possible, but also that the specific theoretical formulations determined by the discourse may alternate and change continuously. It would be surprising indeed if the postwar history - of political compromises with the Catholics in the CDU party, of popularization of ordoliberalist thought and consequently of recruitment from outside Lutheran-Evangelical circles, of German reunification and of European integration and existential crisis - had not entailed some changes to the ordoliberal theoretical apparatus. The question, then, becomes whether the problem structure and the centrality of Ordnung, too, have changed or remained stable. Some indications may be quoted supporting the stability thesis, notably Hien's (2017) work, but also detailed conceptual analyses of the ordoliberal legal structures of the EU, such as Vatiero (2015). Moreover, the main policy goals of ordoliberalism have remained stable throughout the period: state-guaranteed competition order, hard-line anti-inflationist monetary policy, and uncompromising enforcement of debtor obligations. These are only indications; the research necessary to answer the question appropriately remains to be conducted. The present paper has provided the foundation necessary for us even to formulate the question in the first place. 


\section{References}

Agamben G (2009a) Philosophical Archaeology. Law Crit 20:211-231

Agamben G (2009b) What is an Apparatus. In: What is an Apparatus and Other Essays. Stanford University Press, pp 1-24

Agamben G (2011) The Kingdom and the Glory: For a Theological Genealogy of Economy and Government. Stanford University Press, Stanford, California

Althaus P (1923) Staatsgedanke und Reich Gottes. Beyer

Althusser L (2014) Du " Capital " à la philosophie de Marx. In: Lire Le Capital. PUF, Paris, pp 1-80

Aquinas T (1975) Summa Theologiae: Divine government. Eyre \& Spottiswoode, London

Augustine (1960) The City of God against the Pegans. Loeb, London

Barth K (2010) Der Römerbrief, Zweite Ausgabe (1922). Theologischer Verlag Zürich, Zürich

Barth K (1934) Nein!: Antwort an Emil Brunner. C. Kaiser, München

Boarman PM (ed) (1955) Der Christ und die soziale Marktwirtschaft. Kohlhammer

Böhm F (1937) Die Ordnung der Wirtschaft als geschichtliche Aufgabe und rechtsschöpferische Leistung, etc. Kohlhammer, Stuttgart

Böhm F (1960) Die Idee des ORDO im Denken Walter Euckens. ORDO Jahrb Für Ordn Von Wirtsch Ges 3:xi-1xiv

Böhm F (1989) The Rule of Law in a Market Economy. In: Peacock A, Willgerodt H (eds) Germany's Social Market Economy: Origins and Evolution. Macmillan, London

Böhm F, Eucken W, Großmann-Doerth H (1989) The Ordo Manifesto of 1936. In: Peacock A, Willgerodt H (eds) Germany's Social Market Economy: Origins and Evolution. Macmillan, London, pp 15-26

Bonefeld W (2010) Free economy and the strong state: Some notes on the state. Cap Cl 34:15-24

Bonefeld W (2012) Freedom and the Strong State: On German Ordoliberalism. New Polit Econ $17: 633-656$

Bonefeld W (2017a) The Strong State and the Free Economy. Rli, London New York

Bonefeld W (2017b) Ordoliberalism and Political Theology: On the Government of Stateless Money. In: Hien J, Joerges C (eds) Ordoliberalism, Law and the Rule of Economics. Hart Publishing, Oxford, pp 273-288 
Bruni L, Oslington P, Zamagni S (2016) Economics and theology special issue: introduction. Int Rev Econ 63:1-5

Brunner E (1978) Das Gebot und die Ordnungen. Entwurf einer protestantisch-theologischen Ethik. Mohr, Tübingen

Bulmer S (2014) Germany and the Eurozone Crisis: Between Hegemony and Domestic Politics. West Eur Polit 37:1244-1263

Calvin J (1911) Institution de la réligion chrétienne, 1st ed. reprint [1541]. Librairie Honoré Champion, Paris

Dathe U (2009) Walter Euckens Weg zum Liberalismus (1918-1934). ORDO Jahrb Für Ordn Von Wirtsch Ges 50:53-86

Davies W (2014) Neoliberalism: A Bibliographic Review. Theory Cult Soc 31:309-317

Dean M (2013) The Signature of Power: Sovereignty, Governmentality and Biopolitics. SAGE

Dietze K von (1947) Nationalökonomie und Theologie. Tübingen-Stuttgart : Furche-Verl.,

Eucken W (1932a) Staatliche Strukturwandlungen und die Krisis des Kapitalismus. Weltwirtschaftliches Arch Z Für Allg Spez Weltwirtschaftslehre 36:297-321

Eucken W (2004) Grundsätze der Wirtschaftspolitik, 7th edn. UTB, Stuttgart, Tübingen

Eucken W (1939) Die Grundlagen der Nationalökonomie. Gustav Fischer Verlag, Jena

Eucken W (1934) Was leistet die nationalökonomische Theorie? In: Kapitaltheoretische Untersuchungen. Gustav Fischer Verlag, Jena, pp 1-51

Eucken W (1943) Die Grundlagen der Nationalökonomie, 3rd edn. Gustav Fischer Verlag, Jena

Eucken W (1932b) Religion - Wirtschaft - Staat: Zur Problematik des Gegenwartmenschen. Tatwelt Z Für Erneu Geistesleb 8:82-89

Feld LP, Köhler EA, Nientiedt D (2015) Ordoliberalism, Pragmatism and the Eurozone Crisis: How the German Tradition Shaped Economic Policy in Europe. ERIS - Eur Rev Int Stud 2:

Foucault M (2008) L’archéologie du savoir. Gallimard, Paris

Freiburger Kreis (1979) Politische Gemeinschaftsordnung: Ein Versuch zur Selbstbesinnung des christlichen Gewissens in den politischen Nöten unserer Zeit. In: Thielicke H, Bismarck P von (eds) In der Stunde Null. Die Denkschrift des Freiburger Bonhoeffer-Kreises. J.C.B. Mohr, pp 26-152

Friedrich CJ (1955) The Political Thought of Neo-Liberalism. Am Polit Sci Rev 49:509-525

Gogarten F (1932) Politische Ethik. Eugen Diederichs Verlag, Frankfurt 
Goldschmidt N (1998) Christlicher Glaube, Wirtschaftstheorie und Praxisbezug. Walter Eucken und die Anlage 4 der Denkschrift des Bonhoeffer-Kreises. Hist-Polit Mitteilungen 5:

Hien J (2017) The Religious Foundations of the European Crisis. J Common Mark Stud 1-20

Hien J, Joerges C (2017a) Das aktuelle europäische Interesse an der ordoliberalen Tradition. Leviathan 45:459-493

Hien J, Joerges C (eds) (2017b) Ordoliberalism, Law and the Rule of Economics. Hart Publishing, Oxford

Hillebrand R (2015) Germany and its Eurozone Crisis Policy: The Impact of the Country's Ordoliberal Heritage. Ger Polit Soc 33:6-24

Hindess B (1977) Philosophy and Methodology in the Social Sciences. Branch Line, Hassocks

Hyppolite J (1974) Genèse et structure de la phénoménologie de l'esprit de Hegel. Aubier Montaigne, Paris

Jähnichen T (2010) Die protestantischen Wurzeln der Sozialen Marktwirtschaft. Ethik Ges

Johnson D (1989) Exiles and Half-Exiles: Wilhelm Röpke, Alexander Rüstow and Walter Eucken. In: Peacock A, Willgerodt H (eds) German Neo-Liberals and the Social Market Economy. Palgrave Macmillan UK, pp 40-68

Koselleck R (2002) The Practice of Conceptual History: Timing History, Spacing Concepts. Stanford University Press, Stanford, Calif

Libera A de (2014) La querelle des universaux : De Platon à la fin du Moyen Age, édition revue et augmentée. Points

Libera A de (2016) L'archéologie philosophique. Cours au Collège de France 2013-2014. Vrin, Paris

Luther M (1931) Vorrede auff die Epistel Sanct Paulus zu den Romern. In: D. Martin Luthers Werke - kritische Gesamtausgabe: Deutsche Bibel. Böhlau, Weimar, pp 2-26

Luther M (1960) Vorlesung über den Römerbrief 1515/1516, Lateinisch-deutsche Ausgabe. Hermann Böhlaus Nachfolger, Weimar

Luther M (1964) Wider die räublischen und mörderischen Rotten der Bauern. In: D. Martin Luthers Werke - kritische Gesamtausgabe, Weimarer Ausgabe. Hermann Böhlaus Nachfolger, Weimar, pp 357-361

Luther M (1966) Von weltlicher Obrigkeit. In: D. Martin Luthers Werke - kritische Gesamtausgabe. Böhlau, Weimar, pp 245-281

Luther M (tran) (2003) Deutscher Bibel. In: D. Martin Luthers Werke - kritische Gesamtausgabe. Böhlau, Weimar 
Magatti M, Martinelli M (2016) Modern individualisms and Christian schism: why what we miss is important. Int Rev Econ 63:51-75

Manow P (2001) Ordoliberalismus als ökonomische Ordnungstheologie. Leviathan 29:179-198

Manow P (2010) Die soziale Marktwirtschaft als interkonfessioneller Kompromiss? Ein ReStatement. Ethik Ges 2010:1-21

Matthijs M, McNamara K (2015) The Euro Crisis' Theory Effect: Northern Saints, Southern Sinners, and the Demise of the Eurobond. J Eur Integr 37:229-245

Mirowski P, Plehwe D (2009) The Road from Mont Pelerin: The Making of the Neoliberal Thought Collective. Harvard University Press, Cambridge MA

Mont Pelerin Society (1947) Liberalism and Christianity. In: Proceedings. Mont Pèlerin, pp 153-169

Mudge SL (2008) What is neo-liberalism? Socio-Econ Rev 6:703-731

Müller-Armack A (1968a) Soziale Irenik. In: Religion und Wirtschaft. Kohlhammer

Müller-Armack A (1948) Das Jahrhundert ohne Gott: Zur Kultursoziologie unserer Zeit. Regensberg, Münster

Müller-Armack A (1968b) Religion und Wirtschaft. Kohlhammer

Nedergaard P, Snaith H (2015) 'As I Drifted on a River I Could Not Control': The Unintended Ordoliberal Consequences of the Eurozone Crisis. JCMS J Common Mark Stud 53:10941109

Ptak R (2009) Neoliberalism in Germany: Revisiting the Ordoliberal Foundations of the Social Market Economy. In: The Road From Mont Pèlerin: The Making of The Neoliberal Thought Collective. Harvard University Press, Cambridge, pp 98-138

Richter M (1997) The History of Political and Social Concepts: A Critical Introduction. Oxford University Press, New York

Ritter J, Gründer K (eds) (1984) Ordnung. Hist. Wörterb. Philos. 6:1249-1310

Röpke W (1944) Civitas Humana. Eugen Rentsch, Zürich

Rüstow A (1932) Freie Wirtscahft, starker Staat. Schriften Ver. Für Socialpolitik 187:62-69

Rüstow A (1955) Wirtschaftsethische Probleme der sozialen Marktwirtschaft. In: Boarman P (ed) Der Christ und die Soziale Marktwirtschaft. Kohlhammer, Köln, pp 53-74

Rüstow A (1960) Paläoliberalismus, Kollektivismus und Neoliberalismus in Wirtschafts- und Sozialordnung. In: Forster K (ed) Christentum und Liberalismus: Studien und Berichte der Katholischen Akademie in Bayern. Karl Zink Verlag, Münschen, pp 149-178

Rüstow A (1945) Das Versagen des Wirtschaftsliberalismus als religionsgeschichtliches Problem. Istanbuler Schriften, Istanbul 
Rüstow A (1946a) Letters to Röpke

Rüstow A (1946b) Letters to Eucken

Schmitt C (2016) Römischer Katholizismus und politische Form, 6th edn. Klett-Cotta

Streeck W (2015) Heller, Schmitt and the Euro. Eur Law J 21:361-370

Tönnies S (2009) Nachwort: Die liberale Kritik des Liberalismus. In: Die Religion der Marktwirtschaft. LIT, Berlin, pp 172-195

Tribe K (2008) Strategies of Economic Order: German Economic Discourse, 1750-1950, Reissue edition. Cambridge University Press, Cambridge

Vatiero M (2015) Dominant market position and ordoliberalism. Int Rev Econ 62:291-306

Young B (2014) German Ordoliberalism as Agenda Setter for the Euro Crisis: Myth Trumps Reality. J Contemp Eur Stud 22:276-287

Young B (2017) What is Neoliberal in Germany's and Europe's Crisis Politics. In: Hien J, Joerges C (eds) Ordoliberalism, Law and the Rule of Economics. Hart Publishing, Oxford, p 129 